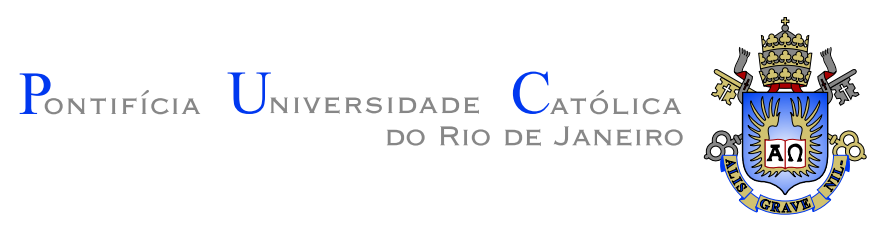

Daniel Fleischman

\title{
An Improved Exact Method for the UBQP
}

\section{Dissertação de Mestrado}

Dissertation presented to the Postgraduate Program in Informatics of the Departamento de Informática do Centro Técnico Científico da PUC-Rio, as partial fulfillment of the requirements for the degree of Mestre.

Advisor: Prof. Marcus Vinicius Soledade Poggi de Aragão 


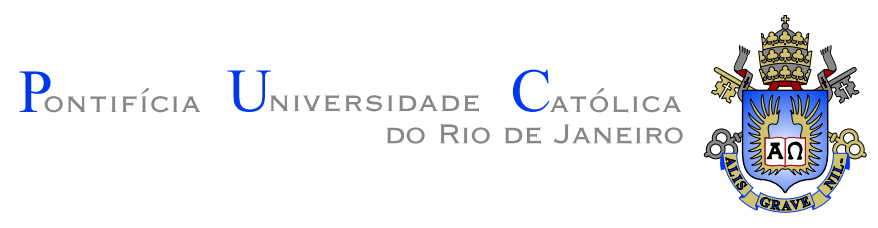

Daniel Fleischman

\section{An Improved Exact Method for the UBQP}

Dissertation presented to the Postgraduate Program in Informatics of the Departamento de Informática do Centro Técnico Científico da PUC-Rio, as partial fulfillment of the requirements for the degree of Mestre.

Prof. Marcus Vinicius Soledade Poggi de Aragão

Adviser

Departamento de Informática - PUC-Rio

Prof. Nelson Maculan Filho

COPPE - UFRJ

Prof. Alexandre Street de Aguiar

Departamento de Engenharia Elétrica - PUC-Rio

Prof. José Eugênio Leal

Coordinator of the Centro Técnico Científico da PUC-Rio

Rio de Janeiro - August 04, 2010 
All rights reserved.

\section{Daniel Fleischman}

Daniel Fleischman graduated from Pontifícia Universidade Católica do Rio de Janeiro in Computer Engineering and Applied Mathematics. During his undergraduate years he participated in undergraduate research projects, mathematics and computer programming competitions, and spent several terms as teaching assistant in Linear Algebra and Computer Architecture.

Bibliographic data Fleischman, Daniel

An improved exact method for the UBQP / Daniel Fleischman; adviser: Marcus Vinicius Soledade Poggi de Aragão. — 2010.

56 f; il. (color.); 29,7 cm

Dissertação (mestrado) - Pontifícia Universidade Católica do Rio de Janeiro, Departamento de Informática, 2010.

Inclui bibliografia.

1. Informática - Teses. 2. Programação semidefinida. 3. Branch-and-bound. 4. Programação não linear. 5. Programação quadrática binária irrestrita. 6. Condições de otimalidade. 7. Geração de colunas. I. Soledade Poggi de Aragão, Marcus Vinicius. II. Pontifícia Universidade Católica do Rio de Janeiro. Departmento de Informática. III. Título. 


\section{Acknowledgments}

To my adviser Professor Marcus Poggi, for his dedication. He has been a great source of knowledge and inspiration.

To my parents, my brother, my grandparents, and all my family for the support and the interest on my work, and for the patience.

To my girlfriend for being with me, even in the days that I could not be with her.

To the While True group. It is always good to have some friends who can laugh at the same jokes you do.

To my coleagues in the ICPC team, Fábio Dias and Roberto Cavalcante, for pushing me further. Thanks for the great years practicing together, and for the trips to San Antonio and Tokyo.

To the members of the teams I coached for the great time, and for the high level discussions. Special thanks to the Dynasty of Samba team, Caio Valentim, Eduardo Cardoso and Guilherme De Napoli for taking me to Harbin.

To my Professors in PUC-Rio, for teaching me with passion and depth.

To the Department of Informatics staff, for the efficiency and the commitment to their work.

To CNPq and PUC-Rio, for the financial support. 


\section{Abstract}

Fleischman, Daniel; Soledade Poggi de Aragão, Marcus Vinicius.

An Improved Exact Method for the UBQP. Rio de Janeiro, 2010. 56p. M.Sc. Dissertation — Departamento de Informática, Pontifícia Universidade Católica do Rio de Janeiro.

Unconstrained Binary Quadratic Programming (UBQP) is widely studied. It is a powerful modeling tool and its associate problem is $\mathcal{N} \mathcal{P}$-hard. In this work a new approach is introduced, which can be used to build an exact algorithm. Also, the fundamental idea behind it can be used in an even wider family of problems. This exact algorithm derived from the new method is highly parallelizable, which is a desired feature nowadays, when the cloud computing is a reality. For reasonably large instances of UBQP, the new method can parallelize to hundreds, or even thousands, of cores easily, with a near-linear speedup.

\section{Keywords}

Semidefinite programming. Branch-and-bound. Nonlinear programming. Unconstrained binary quadratic programming. Optimality conditions. Column generation. 


\section{Resumo}

Fleischman, Daniel; Soledade Poggi de Aragão, Marcus Vinicius. Um Método Exato Melhorado para o UBQP. Rio de Janeiro, 2010. 56p. Dissertação de Mestrado - Departamento de Informática, Pontifícia Universidade Católica do Rio de Janeiro.

A Programação Quadrática Binária Irrestrita (UBQP) é amplamente estudada. Trata-se de uma ferramenta de modelagem poderosa, mas otimizar de um problema $\mathcal{N} \mathcal{P}$-difícil. Neste trabalho uma nova abordagem é apesentada, que pode ser usada para construir um algoritmo exato. Além disso, a ideia básica que fundamenta o trabalho pode ser usado em um espectro ainda mais amplo de problemas. O algoritmo exato derivado do novo método é altamente paralelizável, o que é uma característica desejável nos dias de hoje em que cloud computing já é uma realidade. Para instn̂cias razoavelmente grandes do UBQP, o novo método pode paralelizar a centenas, ou até milhares, de núcleos com facilidade, com um aumento de desempenho quase linear.

\section{Palavras-chave}

Programação semidefinida. Branch-and-bound. Programação não linear. Programação quadrática binária irrestrita. Condições de otimalidade. Geração de colunas. 


\section{Contents}

$\begin{array}{llr}1 & \text { Introduction } & 9\end{array}$

2 Unconstrained Binary Quadratic Programming 11

2.1 Modeling power of UBQP 13

Max Cut 13

Max Clique 14

3 Related Work $\quad 15$

$\begin{array}{lll}3.1 & \text { SDP relaxation } & 17\end{array}$

3.2 Branch and Bound using SDP and the Bundle Method 19

3.3 Relaxing equivalent problems to find a lower bound 21

4 CGI - Column Generation Improvement for Heuristics 23

4.1 Linear Programming 24 simplex 24

$\begin{array}{lll}4.2 & \text { Column Generation } & 27\end{array}$

4.3 The Linear 0-1 Problem 29

4.4 The Proposed Improvement Method 30

4.5 One Last Problem to Solve 32

$5 \quad$ A New Bounding Method 33

5.1 "Direct computation" 34

Minimizing a linear function subject to a convex quadratic constraint $\quad 35$

5.2 "Inverse computation" 37

Solving the "inverse problem" 38

5.3 Further Improving the Bound 39

6 Branch and Bound $\quad 41$

6.1 Relaxation 44

Computing $K_{0}(i)$ and $K_{1}(i)$

6.2 Branching 46

6.3 Heuristics 47

6.4 A slighty modification 48

$7 \quad$ Numerical Results $\quad 49$

7.1 Parallel Computation 51

7.2 Greedy Heuristics 53

8 Conclusion and future work $\quad 54$

$\begin{array}{ll}\text { Bibliography } & 55\end{array}$ 
Hofstadter's Law: It always takes longer than you expect, even when you take into account Hofstadter's Law.

Douglas Hofstadter, Gödel, Escher, Bach: An Eternal Golden Braid. 